\title{
The Investigation of in-Service Elementary School Teachers' Understandings of Inquiry-Based Learning by Using Indonesian Version of Understanding Learning Cycle Test
}

\author{
Irwan Koto ${ }^{*}$ and Agus Susanta
}

\author{
Postgraduate Program of Elementary Education University of Bengkulu \\ *Corresponding author. Email: irwan_koto@unib.ac.id
}

\begin{abstract}
Many scholars have published research studies related to teacher misconceptions about science concepts but a few investigations report teachers' understandings of Inquiry-Based Learning (IBL). To achieve the main concern, Indonesian version of the Understanding of Learning Cycle (ULC) test was developed by translation from English to Bahasa Indonesia and back translation to English. To ensure the quality of translation, the ULC test adopted from Marek, Maier, and McCann (2008) was translated by two scholars who had fluency in Bahasa Indonesia and English. The translated ULC was administered to 31 in-service elementary school teachers. The majority (97\%) of the subject had teaching experiences from 5 to 15 years. The use of translated ULC test indicated that (1) Indonesian version of the ULC can be used to evaluate in-service elementary school teachers' understanding of IBL; and (2) The varieties of misunderstandings about the IBL can be reported: (a) 94\% of subjects discovered misunderstandings about teacher's role during exploration; during concept introduction, (b) only 4\% subjects understood teacher's role as a guide to having students construct knowledge by the use of their learning experience; and @), the majority (97\%) of subjects had misunderstandings the main purpose of concept application to apply new knowledge to a recent situation.
\end{abstract}

Keywords: Inquiry-based learning, In-service elementary school teachers, Indonesian version of learning cycle test.

\section{INTRODUCTION}

Generally, an inquiry as a learning outcome is the process of how to get answers to a problem and the process of how to draw conclusions to a problem [1]. However, an inquiry is a question-driven process that is closely related to the active investigation and the collaboration to generate conclusions.

\subsection{Inquiry-Based Learning}

Inquiry-Based Learning (IBL) is a philosophy and teaching process that guide students to investigate the school environment. As a philosophy, IBL is based on the theory of Vygotsky, Dewey, Piaget, and others which are considered as the philosophy of constructivism. However, it is difficult to trace when inquiry teaching is applied to learning. Inquiry teaching results from long debates about the nature of teaching and learning, specifically related to Piaget, Vygotsky, and Ausubel who developed a constructivism learning philosophy [2]. Related to constructivism learning philosophy, Cakir [3] stated that "Constructivism is more a philosophy, not a strategy" (p. 197). Therefore, IBL is a practical application of constructivist learning philosophy to the teaching and learning process.

Constructivism is a theory based on observation and investigation of how students learn. It infers that learning is an active process of stimulating students to use their prior knowledge and ideas to construct new knowledge through interaction with the learning environment. In other words, learning tends to be both personal experience and social experience. Thus, IBL is identified as the applied form of constructivism into classroom

As a learning theory, constructivism informs teachers with an understanding of how students learn and what they can learn. But, the majority of learning theories do not determine which strategies to implement 
the theory into the classroom. Constructivism teaching is established by teachers in the classroom through a teaching method or model.

\subsection{Learning Cycle}

Learning Cycle cannot be called a method or model but the LC is the relationship of a phase with other phases to design science lessons to gain science experience through inquiry learning process [4]. The previous study published by [5] reported that the LC is a teaching approach based on inquiry. However, this study prefers the LC as a model of teaching since its phases represent an inductive application of the information process [6].

The three phases of LC are the exploration phase, concept introduction phase, and concept application phase derived from Piaget's mental function model of assimilation, accommodation, and organization [7]. Table 1 presents the relationships between Piaget's model of mental functioning and the three phases of LC adapted from [5]

Table 1. Phases of learning cycle and mental function model

\begin{tabular}{|l|l|}
\hline Learning Cycle Phases & Mental Function Model \\
\hline Exploration & Assimilation \\
\hline Concept introduction & Accommodation \\
\hline Concept application & Organization \\
\hline
\end{tabular}

The Exploration phase provides an opportunity for students to carry out the process of assimilating the science concepts. The process of assimilation between the new concepts and the former concepts stored in memory affects dis-equilibration. The Concept Introduction phase aims to guide students in interpreting data and learning experiences that cause re-equilibrium and accommodation of concepts. The Concept Application phase provides students an opportunity to connect the developed science concepts to everyday applications and to other concepts through Piaget's cognitive process called organization.

To employ effectively a teaching approach, inservice elementary teachers need to comprehend how to apply the learning cycle in the classroom since the learning cycle can be implemented in inquiry science from the elementary level to the college level [8]. One of the means to identify the understanding of in-service teachers concerning the inquiry-based learning can be done via diagnostic tests. The diagnostic test adopted in this study is the test developed by [8]. This test is known as Understanding of the Learning Cycle (the ULC) which is the improvement of the Learning Cycle Test (LCT) developed by [9].
The ULC test consists of 18 objective multiplechoice items with 2,3 , or 4 choices (the first tier) accompanied by four alternative choices of reasons (the second tier) as shown in Table 2.

Table 2. Indonesian Version of ULC Diagnostic Test*

\begin{tabular}{|l|l|}
\hline Tier & Stem, Alternative Answer and Reason \\
\hline First & $\begin{array}{l}\text { Selama fase kedua, kegiatan belajar yang } \\
\text { dilakukan oleh siswa adalah ... } \\
\text { A.Gejala alam didiskusikan dan diekplorasi. } \\
\text { B.Siswa menyelidiki gejala alam secara } \\
\text { langsung. } \\
\text { C.Siswa melaporkan data di depan kelas } \\
\text { dan menganalisisnya }\end{array}$ \\
& $\begin{array}{l}\text { Alasan: } \\
\text { A.Siswa menjelaskan secara lisan } \\
\text { pengalaman belajar yang diperoleh } \\
\text { dengan bimbingan guru. } \\
\text { B.Guru menginterpretasikan data untuk } \\
\text { siswa. } \\
\text { C.Guru memberi izin siswa bekerja individu } \\
\text { untuk mengkonstruksi konsep. } \\
\text { D. Kegiatan yang menggunakan benda- } \\
\text { benda konkrit penting bagi siswa dengan } \\
\text { gaya belajar konkrit }\end{array}$ \\
\hline
\end{tabular}

Note Translation to Indonesian language from Edmund A. Marek, Steven J. Maier dan Florence McCann pp. $(375-389)$

The ULC test was developed to measure understanding of the learning cycle and its relationship with Piaget's theory of mental function (see Table 1)[8]. Of the 18 items in the ULC test, 4 items were used to measure understanding of the exploration phase, 3 items for the explanation phase, 6 items for the application phase, and 5 items for measuring the understanding of the learning cycle in general and its application including the sequence of the phases, stage of development, and classroom environment.

The result of the previous study done by involving 117 students who took the science education methods courses at Midwestern University (USA), it was found that 18 items of the ULC test (a) can be used to measure understandings and misunderstandings of the learning cycle and (b) has an internal consistency of test items with Cronbach's alpha coefficient of 0.791 [8].

Based on the results of the literature review, it is indicated that the Indonesian version of the ULC test is not yet available. Consequently, the English version of the ULC test needs to be translated into the Indonesian language. Every item in the ULC test was translated into the Indonesian language without losing the meaning and expression of every word contained in the original version. Crystal [10] defined translation as a process "the meaning and expression in one language (source) is tuned with the meaning of another..." (p. 346). Furthermore, Regmi, [11] stated the translation process 
needs translators who can speak in two languages. In other words, the translation process will give optimal results if it involves translators who are fluent in English and Indonesian actively and passively to ensure the quality of translation.

Therefore, the research aims of this study are to (a) have the Indonesian version of the understanding learning cycle test and (b) investigate in-service teachers' understandings of inquiry-based learning via the use of the Indonesian version of the understanding learning cycle test.

\section{METHODS OF THE STUDY}

The descriptive study was performed to achieve the intended objectives. There were 31 in-service teachers teaching science in public elementary schools who participated in this study. As part of a survey, teachers completed three demographic questions that comprised teaching experience, age, and gender.

Table 3. Demographic information of participants

\begin{tabular}{|c|c|}
\hline Demographic Variables & Frequency (\%) \\
\hline \multicolumn{2}{|l|}{ Teaching Experience } \\
\hline a. Fewer than 5 years & $17(54,8 \%)$ \\
\hline b. $5-10$ years & $4(12,9 \%)$ \\
\hline c. $10-15$ yers & $9(29,1 \%)$ \\
\hline d. 15 or more years & $1(3,2 \%)$ \\
\hline \multicolumn{2}{|l|}{ Age } \\
\hline a. Fewer than 30 tahun & $18(58,1 \%)$ \\
\hline b. $30-34$ years & $3(9,6 \%)$ \\
\hline c. $35-44$ years & $10(32,3)$ \\
\hline \multicolumn{2}{|l|}{ Gender } \\
\hline a. Male & $11(36 \%)$ \\
\hline b. Female & $20(64 \%)$ \\
\hline
\end{tabular}

Table 3 displays a summary of the descriptive statistics of elementary school teachers involved in this study. As shown in the observed range of teaching experience (see Table 3), approximately 55\% of teachers have less than five years of teaching experience categorized as novice teachers [12], and only $3.2 \%$ of respondents have teaching experience of more than 15 years. Looking at teaching experience, the largest group of teachers $(58 \%)$ were less than 30 years old.

\subsection{The Translation Stage of English Version of the ULC to the Indonesian Version.}

The ULC is a diagnostic test that can be used to assess the teachers' understanding of inquiry-based learning. The ULC is a multiple-choice diagnostic test providing a choice of answer reasons (two-tiered test). Since the ULC is in English, it needs to be translated into the Indonesian language to make it easier for respondents to understand the meaning of each propositional statement and every reason contained in the ULC test.

The translation and back translation model was adopted from Brislin [13] considered the appropriate method for this study [14]. A similar study reported by Koto [15] points out that Brislin's model was used to translate the Kolb-Learning Style Inventory (K-LSI) from English to Indonesian Language. The K-LSI was used to identify the preference of tenth-grade students' learning styles.

This model requires at least two translators who can communicate in two languages to perform the process of translating the text qualitatively. The first translator translates from English to Indonesian language and the second translator translates from Indonesian to English. The two translators can speak Indonesian and English actively and passively because both of them have completed their Masters and Doctoral program in the western country university (the USA and Australia).

Regarding how to translate the original version of ULC, the phases of the translation process of the Indonesian version are explained as follows:

Phase-1: Two translators have the ability of bilingual language. They are fluent in both English and Indonesian language. Since the original version was designed for individuals speaking English and living in Western culture, the translator paid attention to contextual rather than textual concerns.

Phase 2: The first translator translated the English version into the Indonesian language (forwardtranslation). By using the Indonesian version to maintain the accuracy of word or phrase equivalences, the first translator focused on achieving linguistic and contextual equivalence with the original version. The translation that had captured the original meaning was adopted. However, the meanings were not similar in two languages after being translated, the appropriate adjustment is made to the Indonesian translation by looking back to the original version.

Phase 3: The ULC was translated into the Indonesian language, it was translated back into English (backwardtranslation) by the second translator without looking at the original version.

Phase 4: The ULC translated back to English was compared to the original version by the first and the second translator to check accuracy and equivalence. 
Phase 5: Phrases or words congruent were discussed jointly between the first and second translators for revisions of the Indonesian version of the ULC test.

\subsection{The administration of the Indonesian version of the ULC test}

Following translation, the Indonesian version of the ULC test was administered to 31 elementary school teachers during the professional development program. The ULC test consists of two parts; the first part is the respondent's identity and the second part is the ULC test which consists of 18 statements (stimulus) and the choice of answer (response) and the reasons for the choice of answer. Teachers took approximately 15-20 minutes to complete the ULC test. disediakan bahan-bahan/alat-alat dan kesempatan untuk mengumpulkan data) is $22 \%$. Table 4 displays that the classroom teachers are more successful in deciding the desired answer to the first tier of the question rather than in selecting the educational reason for their answer. It means that elementary school teachers participated in this study recognized the wanted answer whereas they do not know the reasons why these are correct. In general, this study reported that in-service teachers hold misunderstanding regarding the learning cycle as inquiry-based learning approach. Similarly, the study carried out by Marek, [7] published that preservice teachers had misunderstanding about the learning cycle as inquiry teaching approach that denotes the discipline of science. The selected understanding and misunderstanding related to inquiry-based learning are discussed as follows:

Table 4. Percentages of in-Service Teacher Choosing the Wanted First Tier and Combination

\begin{tabular}{|c|l|c|c|}
\hline Item & \multicolumn{1}{|c|}{ Learning Cycle } & First Tier & Combination \\
\hline 1 & Phase 3 (Application) & $29 \%$ & $13 \%$ \\
\hline 2 & The use of the learning cycle in any field of study & $97 \%$ & $13 \%$ \\
\hline 3 & Phase 1(Exploration) & $58 \%$ & $22 \%$ \\
\hline 4 & Phase 2 (Concept introduction) & $48 \%$ & $29 \%$ \\
\hline 5 & Phase 3 (Application) & $35 \%$ & $3 \%$ \\
\hline 6 & Phase 2 (Concept introduction) & $19 \%$ & $6 \%$ \\
\hline 7 & Phase 3 (Application) & $26 \%$ & $16 \%$ \\
\hline 8 & Piaget' theory of metal process functioning & $29 \%$ & $19 \%$ \\
\hline 9 & Phase 1 (Exploration) & $22 \%$ & $10 \%$ \\
\hline 10 & Order of phases of learning cycle & $84 \%$ & $61 \%$ \\
\hline 11 & Suitable learning activity related Phase 3 & $19 \%$ & $0 \%$ \\
\hline 12 & Phase 1 (Exploration) & $55 \%$ & $35 \%$ \\
\hline 13 & Teacher behavior during phase 1 & $52 \%$ & $35 \%$ \\
\hline 14 & Classroom setting during learning cycle & $61 \%$ & $55 \%$ \\
\hline 15 & Phase 2 (Concept introduction) & $45 \%$ & $39 \%$ \\
\hline 16 & The use of the learning cycle for developmental stage of learners & $26 \%$ & $26 \%$ \\
\hline 17 & The main role of phase 3 & $55 \%$ & $6 \%$ \\
\hline 18 & The appropriate activity during phase 3 & $16 \%$ & $3 \%$ \\
\hline
\end{tabular}

\section{RESULTS AND DISCUSSION}

Percentages of the wanted answers given by inservice teachers to the first tier of a two-tier question in the Indonesian version of the ULC and correct answers to both of the tier (combination) were evaluated. The significant results reported in Table 4 is that the percentages of the wanted answer to both tiers of the ULC are lower than the percentage of correct answers to the first tier.

For example, the percentage of correct answers to the first tier of question 3 "During the first phase, teacher" (Apakah yang dilakukan oleh guru selama fase 1 ?) is $58 \%$, but the percentage of needed answers "Students should be provided with the materials and opportunity to gather data" (Siswa seharusnya

\subsection{Exploration Phase}

Items 3, 9, 12, and 13 aim to assess the teachers' understandings of phase 1 (exploration). Based on their answers to these four items, the majority of teachers had misunderstandings in the exploration phase. The percentage of choosing the wanted answer combinations were $22 \%, 10 \%, 35 \%$, and $35 \%$, correspondingly (Table 4). For example, item 9 addressed the teachers' role during exploration. Approximately 9,7\% of teachers gave the wanted answer combinations (see Table 5). However, $77,4 \%$ of teachers perceived that during the first phase of the learning cycle, a teacher demonstrates and explains a basic science concept since $48,7 \%$ of them have considered that a learner requires a mental framework before the investigation. 
Regarding the teacher's role during the exploration phase, a teacher should provide students with a worksheet to guide them in doing hands-on activities or experiments. More specifically, Marek [7] points out that teacher not only prepares the necessary materials and equipment but also provides students with procedures (written or oral) that guide students in recording their observation. after students construct concepts to apply the concept to new situations by doing hands-on activities. 48,4\% of teachers provided the alternative answer: "Phase one after the information is given to students, they are given the opportunity to make a connection to new concepts" (29\%). As seen in Table 5, only 3,2\% of in-service teacher understand the purpose of Phase 3 is to: "Expand the previously developed concept into a new context (first tier) because new knowledge becomes more useful when applied to a new situation."

Table 5. Percentages of Teacher Choosing Wanted First Tier and Combination

\begin{tabular}{|c|c|c|c|c|c|c|c|}
\hline Item & Propositional Statement correlated to & First & \multicolumn{5}{|c|}{ Second Tier } \\
\hline \multirow[t]{5}{*}{9} & \multirow{5}{*}{$\begin{array}{l}\text { Teacher's role during the first phase of } \\
\text { learning cycle }\end{array}$} & Tier & A & $\mathrm{B}$ & $\mathrm{C}$ & $\mathrm{D}$ & Total \\
\hline & & $\mathrm{A}$ & $45,5 \%$ & $12,9 \%$ & $0,0 \%$ & $19,3 \%$ & $77,4 \%$ \\
\hline & & $\mathrm{B}$ & $3,2 \%$ & $0,0 \%$ & $9,7 \%$ & $9,7 \% *$ & $22,6 \%$ \\
\hline & & $\mathrm{C}$ & $0,0 \%$ & $0,0 \%$ & $0,0 \%$ & $0,0 \%$ & $0,0 \%$ \\
\hline & & $\mathrm{D}$ & $0,0 \%$ & $0,0 \%$ & $0,0 \%$ & $0,0 \%$ & $0,0 \%$ \\
\hline & & & & & & & \\
\hline \multirow[t]{5}{*}{6} & \multirow{5}{*}{$\begin{array}{l}\text { The main purpose of phase } 2 \text { : Introduction } \\
\text { concept) }\end{array}$} & & A & B & $\mathrm{C}$ & $\mathrm{D}$ & Total \\
\hline & & A & $0,0 \%$ & $3,2 \%$ & $22,6 \%$ & $0,0 \%$ & $25,8 \%$ \\
\hline & & $\mathrm{B}$ & $0,0 \%$ & $6,4 \%$ & $6,4 \% *$ & $6,4 \%$ & $19,2 \%$ \\
\hline & & $\mathrm{C}$ & $6,4 \%$ & $9,7 \%$ & $9,7 \%$ & $6,4 \%$ & $32,2 \%$ \\
\hline & & D & $0,0 \%$ & $3,2 \%$ & $9,7 \%$ & $9,7 \%$ & $22,6 \%$ \\
\hline & & & & & & & \\
\hline \multirow[t]{5}{*}{5} & \multirow{5}{*}{$\begin{array}{l}\text { The main purpose of the third phase: } \\
\text { Concept application }\end{array}$} & & A & B & $\mathrm{C}$ & D & Total \\
\hline & & A & $6,4 \%$ & $3,2 \% *$ & $12,9 \%$ & $12,9 \%$ & $35,5 \%$ \\
\hline & & B & $0,0 \%$ & $0,0 \%$ & $0,0 \%$ & $0,0 \%$ & $0,0 \%$ \\
\hline & & $\mathrm{C}$ & $16,1 \%$ & $0,0 \%$ & $16,1 \%$ & $32,2 \%$ & $64,5 \%$ \\
\hline & & D & $0,0 \%$ & $0,0 \%$ & $0,0 \%$ & $0,0 \%$ & $0,0 \%$ \\
\hline
\end{tabular}

Note *: wanted answer combination

\subsection{Concept Introduction Phase}

Following exploration, the concept introduction is performed which is a difficult phase to do properly [7]. To investigate teachers' understanding of this phase, items 4, 6, and 15 are used. Only 19,2\% of teachers enabled to point out the main objective of phase 2 is to guide students to construct an understanding of science concepts based upon their experiences (see Table 5). Conversely, two alternative responses selected were that the science concept is developed in phase $3(32,2 \%)$ and phase $1(25,8 \%)$. The desired answers combination selected by 31 in-service teachers was $6,4 \%$. It seems that the majority of classroom teachers $(94 \%)$ confused the meaning of the introduction concept.

\subsection{Concept Application Phase}

There were six items to identify in-service teacher understandings concerning the application phases (see Table 4). For example, item 1 questioned, "At what phase of learning cycle do students arrange the concept they have recently studied with other phenomena?" Approximately, $13 \%$ of 31 classroom teachers chose the correct answer. The wanted answer is during phase three
The Indonesian version of the ULC diagnostic test could become an alternative instrument for evaluating in-service teachers' understanding the inquiry-based learning. The extensive research has been done to determine how the teacher perceive and practice the process of inquiry-based learning in a science classroom. For example, Greeno [16] and Edelson [17] revealed that the teacher's role in inquiry-based learning is to provide students with authentic activity to motivate them to acquire new knowledge and to incorporate it into their existing knowledge.

\section{CONCLUSIONS}

Doing the translation of research instrument, such as the ULC, from English to Bahasa Indonesia is a challenging task because language knowledge skills of translators is a key element contributing to the validity of research instrument when the transformation of a language happened [18]. Based on the evidence of the study, there are two conclusions that can be stated.

Firstly, the Indonesian version of ULC can be used as the research tool since it is easy to administer and 
grade. Thirty-one in-service teachers participated in the study capture undoubtedly the meaning of 18 -item, multiple-choice, and two-tiered diagnostic test.

Secondly, the Indonesian version provides sound examination of understandings and misunderstandings of inquiry-based learning. Although the theoretical framework of the learning cycle is rooted in the similar theoretical underpinnings of inquiry-based learning, further study needs to be done to evaluate whether the Indonesian version of ULC is the most suitable tool for assessing teacher's understanding of the enacted inquiry-based learning in classrooms.

\section{ACKNOWLEDGMENT}

The authors would like to express thankfulness to 31 elementary teachers participating voluntarily in this research study.

\section{REFERENCES}

[1] F. Abd-El-Khalick, et.al, "Inquiry in science education: international perspectives," Science Education, vol. 88, pp. 397-419, 2003.

[2] D. D. Minner, A. J. Levy, and J. Century, "Inquiry-based science instruction: What is it and does it matter? Results from a research synthesis years 1984 to 2002," Journal of Research in Science Teaching, vol. 47, no. 4, pp. 474-496. 2009.

[3]. M, Cakir, "Constructivist approaches to learning in science and their implications for science pedagogy: A literature review," International Journal of Environmental \& Science Education, vol. 3, no. 4, Oct, pp. 193-206, 2008.

[4] E. A. Marek, T. A. Laubach, and J. Pedersen, J, "Preservice elementary school teachers' understandings of theory based science education," Journal of Science Teacher Education, vol 14, no. 3, pp. 147-159, 2003.

[5] E. A. Marek and A. M. L. Cavallo, The Learning Cycle: Elementary School Science and Beyond. Portsmouth, NH: Heinemann, 1997

[6] B. Joice, M. Weil, and E. Calhoun, Models of Teaching. Centers for Teaching and Technology Book Library. 2003. https://digitalcommons.georgiasouthern.edu/ct2library/96

[7] E. A. Marek, "Why the learning cycle?" Journal of Elementary Science Education,vol. 20, no. 3, pp. 63-69, 2008.
[8] E.A. Marek, S. J. Maier, and F. McCann, "Assessing understanding of the learning cycle: the ULC". Journal Science Teacher Education, vol. 19, pp. 375- 389, 2008

[9] A. L. Odom, J. Settlage, "Teachers' understanding of the learning cycle as assessed with a two-tier test," Journal of Science Teacher Education, vol. 7 no. 2, pp.123-142, 1996

[10] D. Crystal, The Cambridge encyclopedia of language. Cambridge, UK: Cambridge University Press.

[11] K. Regmi, J. Naidoo, and P. Pilkington, "Understanding the process of translation and transliteration in qualitative research," International Journal Qualitative Methods, vol. 9, no. 1, pp.16- 26, 2010.

[12] A. C. Colley, "What can principals do about new teacher attrition?" Principal-Teaching the Teachers, vol. 81, no. 4, pp. 22-24, 2002.

[13] R. W. Brislin, "Back-tanslation for cross-cultura research", Journal of cross-cultural psychology", vol. 1, pp. 185-216. 1970.

[14] P. S. Jones, J. W. Lee, L. R. Philips, X. E. Zhang, and K. B. Jaceldo, “An adaptation of brislin's translation model for cross-cultural research," Nursing Research, vol. 50, no. 5, pp. 300-304, 2001.

[15] I. Koto, S. W. Ningsih, and D. H. Putri, "Can the indonesian version of kolb learning style identify learning style preferences of high school students?", Advances in Social Science, Education and Humanities Research, 253. pp. 50-52, 2019.

[16] J. Greeno, A. Collin, and L. B. Resnick, "Cognition and learning,"in R. Calfee and D. Berliner, Eds. Handbook of educational psychology. New York: Macmillan, 1996.

[17] D.C. Eldelson, D. N. Gordin, and R.D. Pea, "Addressing the challenges of inquiry-based learning through technology and curriculum design," The Journal Of The Learning Sciences, vol. 8, no. 3\&4, pp. 391-450, 1999.

[18] J. Wong and M. Poon, "Bringing translation out of the shadows: Translation as an issues of methodological significance in cross-cultural qualitative research," Journal of Transcultural Nursing, vol 21, no. 2, pp. 151-158, 2010. 